\title{
Business Logistics Processes in the Global Context
}

\author{
Pavel Ceniga ${ }^{1}$, Viera Šukalová ${ }^{2}$ \\ ${ }^{1,2}$ University of Žilina, Faculty of Operations and Economics of Transport and Communication, Žilina, Slovakia \\ E-mails: ${ }^{1}$ pavel.ceniga@fpedas.uniza.sk (corresponding author); ${ }^{2}$ sukalova@fpedas.uniza.sk
}

Received 11 February 2017; accepted 18 April 2017

\begin{abstract}
Many organizations feel currently threatened by globalization. Grows uncertainty and market behaviour and there are some problems with effective use of resources; it came to the real competition. The current trend in the development of logistics says that wins only the fastest, cheapest and most efficient in terms of logistics productivity. Management structure of logistics processes is important for planning and management elements of the supply chain, because it is a systematic follow-up on the strategy of the company and its involvement in the supply chain; the masses are also linked to the competitiveness of enterprises. Equally important is the principle of modern management, knowledge and innovation. Under improving of the organization of logistics processes we can understand the necessity to improve the strategy, flexibility parameter setting while maintaining economic benefits and improvement of management, lifelong learning and innovation. Business environment requires new structural form as the supply chain to the path towards the ideal of perfect quality, reducing complexity, increasing speed and building strong competencies enabling swift reaction to changes in the environment. It also calls for a new style of management, based on the application of ethical principles and morals. On top of this effort is the customer, current and also potential. Worldwide leading industrial companies use in management logistical principles that offer a suitable alternative.
\end{abstract}

Keywords: management, logistics, globalization, process, business, supply chain.

JEL Classification: F69, M16, M21.

Conference topic: Business Logistics Process.

\section{Introduction}

Modern enterprise management in the time of globalization asks to use new methods and tools to eliminate threats, risks, and constraints and also to maintain the market competitiveness. Modern management in this era needs the application of an unconventional approach and new managerial tools and practices. To this change came this information and communication technology in all parts of the company. Flexibility and the ability to respond promptly and accurately to the changes becomes a huge competitive asset. Only those companies that are able to fulfil requirements have given a chance to survive (Ceniga, Šukalová 2012). We can say, that management of logistics activities in the function of satisfying the consumer has become one of the most attractive areas of the strategic management in the last ten years, therefore, managers seek for strong competitive weapon in the development of own logistic system in order to differentiate their offers in comparison to others (Melovič et al. 2015).

The article is focused on the current processes of the Business Logistics in the context of the process of globalization. The main objective is to define Business Logistics in terms of different types of processes, assess their segmentation and constitute fundamental evaluation methods of these processes. The emphasis is on the integration of essential business processes. Important attention is paid to logistics in the era of globalization based on input on international markets, explaining the mission of Logistics management and acceptances principles of Lean logistics. Based on an analysis of the assessment of the situation in Slovakia with Logistics exposing problem areas, which is necessary to deal with in the future. The solving of the problems is also reflected in the increased quality of ongoing processes Business Logistics, which are irreplaceable qualified Logistics managers. Their new competences and skills, using of advanced techniques and methods to solve logistical problems may significantly affect the efficiency of processes and contribute to positive economic results.

(C) 2017 P. Ceniga, V. Šukalová. Published by VGTU Press. This is an open-access article distributed under the terms of the Creative Commons Attribution (CC BY 4.0) License, which permits unrestricted use, distribution, and reproduction in any medium, provided the original author and source are credited. 


\section{Business Logistics}

Business Logistics is part of the so-called micro logistics. This includes enterprise systems of production and consumption. These systems address issues of material flow, energy and information, both in terms of time and space outside as well as inside the company, these issues of storage, transport, handling, and the like.

The Business Logistics explores the processess:

- Pre-production - procurement and purchase of material;

- Manufacturing - handling devices, vehicles, warehouses inside the company;

- Post-production - sales, customer service, delivery of products to consumers.

The basic element of Business Logistics is material and the associated material flow. Material flow is shown in the material flow, which is organized transfer of any items that are necessary to make the transition process in the production system and between elements of the reporting system and its surroundings. The subject of Business Logistics is generally secure transport, handling and storage of materials, goods and services, away from the vendor, passing through the enterprise to the final consumer. It follows that the logistics business is mainly associated with physical activity associated with the movement of materials, raw materials, goods and services (Pernica 2004).

The content of Business Logistics is:

-Organizing, planning, provision, implementation and monitoring of all relocation and storage processes in the company;

- Own realization of physical processes that are expressed in the material flow;

- All those activities are related, respectively concerned with information flows.

Business Logistics consists of:

- Purchasing and Procurement Logistics;

- Production Logistics;

- Distribution Logistics.

Business Logistics is linked to marketing; it addresses the availability of the product at the right time, right place, at the required service level and at an optimal level cost. By efficient logistics, an enterprise can reduce the level of inventories of finished products and raw materials, and thereby release sufficient funds that can be used, for example on investment. Logistics in company thus allows a reduction in opportunity cost. It is important to realize that the logistics are greatly influenced by the important financial indicators of the company. The enterprise should therefore pay sufficient care to ensure proper and efficient functioning logistics.

\section{Logistics Process}

The process, as a concept function is in Slovak Language Dictionary defined as a course regularly following individual stages of the development something what stays in the permenet causality, making uniform sequence, the development cycle (Viestová 2007). Taking into consideration the scope of present issues, deliberations will concentrate on analysis in the context of the enterprise. Due to logistics processes flow process of goods and accompanying information is raised and carried out, which combines the production system and system of use. Therefore, not only these processes, which activate the flow of business like goods, but also the ones which enable appropriate flow of information. The information function can be carried out for example through the process of customer service.

\section{Basic types of Logistics Processes}

As part logistics processes it is possible to distinguish primary and supporting processes. Primary logistic processes combine the processes of supply, production and distribution, changing temporal, spatial, quantitative, quality and genre properties (attributes) of goods and information. These processes consist of chains flows processes materials and goods, and complementary flows of information. Activities and storing, transport, accepting goods, shipment of goods, waste management and service, as well as relationship with the manufacturing process, with suppliers and customers belong to partial flow processes of materials and goods.

In contrast to the primary logistic processes, which must be carried out in principle all production companies, supporting logistic processes depend on the concept and management model implemented in the company. They relate to the management and further development of base processes; they include strategic, administrative and operating planning processes and making decision shaping, coordination and optimalization logistics system. In particular, these include activities such as planning and control logistics costs and benefits, the development strategy of logistics, protecting effectiveness and efficiency of logistic systems, implementing logistic projects, development and implementing logistics technolohgy, training personnel and improving management of knowledge, innovations and use of logistics at inserting new products, etc.

\section{Segmentation of Logistics Processes}

We can segment logistic processes in view of contribution into creating value added. Manganelli and Klein (1998) say that the process consists of three basic types of activities: 
- Action creating the added value (the most significant form a customer point of view, as well as enterprise);

- Transport action associated with providing products of the process;

- Control measures, used primarily to control the flow of results of the process.

Processes can be divided from the added value point of view on following groups:

- Primary process - directly creating added value with strait relationship with customers (main processes starting and ending on the market and support processes - triggered by main processes with shorter rank connected with wishes and customers expectations;

- Duplicate/secondary processes - indirectly creating added value with indirect connection with customers (they support processes directly creating added value);

- Third-rate processes - relatively associated with creating added value (relative connection with customers);

- Processes not creating added value - not showing connection with customers (potential signs of wasting development customer complaint, repeating works, marketing corrections etc.).

\section{Methods of Logistics Processes Evaluation}

It is necessary to examine the effectiveness of processes in production companies; there are more different ways how to do it. Using available in literature methods, technology, economic indicators can make in-depth analysis of the current enterprise situation, as well as to provide formation of itsw effectiveness while carrying out a transformation selected areas. We can use organizational methods such as method based on Ishikawa diagrams, Experts method Pareto diagrams or method of tree purposes. Key principles which should be considered implementing a proposed action are:

- Purpose concentrating action,

- Ishikawa diagram constitutes the map of action,

- The method of experts allows on quantification influence of individual causes on the effect,

- Pareto diagrams are constituting the basis of detecting the most important causes problems,

- The method of tree purposes allows establishing the variant of improvement with the highest probabilities effective realization (Drahotský, Řezníček 2003).

Applying this proceeding gives the possibility to show potential to make changes in applied dissolutions of the organization physical flows and information, in order to reduce logistics costs and achieve better effects of functioning enterprise. Many reserves being able to contribute lower on the improvement in the existing state are sticking in logistics costs.

\section{Logistics in the Globalization Process}

With the concept of globalization is currently being encountered in almost all areas of our life (economics, politics, culture, communication, environment, etc.), is a worldwide phenomenon observed especially in recent decades and most comprehensive external factors that affect the quality of life of individuals and entire company. Despite the absence of a clear definition of this term, the current theory knows several shop windows in which the author describes the meaning of globalization from various angles. For better orientation, we mention some of them. Globalization is a global process that makes the world, its economic systems, and national communities more integrated and more mutually dependent on each other (Pichanič 2004). Globalization processes supported internationalization, information technology; logistics systems at the highest level and advanced communication have created a global market where there are virtually no restrictions. Globalisation and liberalization of the world economy has brought new challenges for managers of manufacturing companies. In order to achieve and maintain the competitiveness of their businesses must respond flexibly to the constantly new ideas from customers. To a successful competitive struggle are high quality products that can satisfy the ever-increasing demands of customers (Bauman 2000). This is connected with the constant pressure and the processes that provide inputs for the production of products, the production itself, but also the control and distribution. Quality assurance in all these processes must be linked with the least, respectively reasonable costs that the resulting product has an attractive and accessible to potential customers. Pressure to reduce costs necessitates optimization and coordination of material, financial and information flows associated with the production and distribution of products. It is these areas are part of logistics management. According to Verhetsel et al. (2015) the logistics sector is a major stakeholder in the fragmentation of industrial production processes coming along with globalization. The organization of the spatial networks of logistics companies is one of the most important strategic decisions in this respect that they have to make.

The management of procurement processes taking place in the manufacturing plant there are a number of logistics methods, the application of which can be optimized their course. In addition to classical methods they are also modern methods capable of achieving significant time and cost savings. With these methods it is possible to optimize of the supply chain, but also the logistics chain as a whole, comprising suppliers, manufacturing enterprise and its customers. Such complex applications, it is possible to achieve a synergistic effect in streamlining the activities of the manufacturing enterprise. 
The development of logistics in the 21 st century is strongly influenced gain a competitive advantage in the global market; assessing the quality parameters of world class - World Class Logistics (WCL) in providing logistical services. WCL main parameters are reducing the consumption of time on logistics processes; reducing logistics costs; improving the quality of logistics services. Logistics is a tool that can be effectively used to gain competitive advantage and its importance is now recognized worldwide. In connection with this, we can identify increased demand for professionals in Slovakia and also abroad. It is caused by the fact that the importance of logistics, not only in industry, but it covers virtually all businesses and organizations.

Logistics costs are in addition to many businesses have become a critical problem due to the ongoing globalization of the industry. Although the strong emphasis on areas such as quality and customer service, cost reduction is considered the most important factor. Globalisation has affected the logistics of increased competition worldwide, forcing companies to seek new ways to differentiate themselves (Verstrepen et al. 2005). They focus on the logistics to the domestic market were able to provide reliable and flexible service than foreign competitors. At the same time that Slovak companies today increasingly cooperate with other countries, resulting in the supply chain between the company and its business partners extended, it becomes more costly and complex. For the business to be able to take full advantage of global opportunities, we need a good logistics system, including qualified professionals. It is also known, that with the growing importance of logistics and supply chain economics to global industries, firms organizing their industrial activities and locating their warehousing and operational centers must increasingly consider the availability, quality and cost of a range of transportation services (Lindsey et al. 2014). To achieve sustainable competitive advantage, suppliers must not only develop flexibility capabilities for intra-organizational manufacturing processes but also invest effort in aligning their supply chain partners in order to establish a flexible and adaptable supply chain (Yu et al. 2016).

\section{Entrance on International Markets} follows:

Systematized the general factors that affect international businesses entering global markets, can be classified as

- Market potential;

- Geographical diversification;

- Excess production capacity and low cost advantage as a result of achieving economies of scale and effects of experiential curve;

- Generating growth in foreign markets through products on the domestic market, approaching the end of its life cycle;

- Sources of new products and ideas;

- Foreign competitors in the domestic market.

It appears that on entry to the markets of Western companies in Central and Eastern Europe were virtually play on all the above factors, and is considered to be the dominant opportunity to expand to new, emerging markets. In case of allocation of production it was to achieve cost savings through cheap labour, generally in less demanding technologies. With this reality and contradictory experiences with it the question arises, what should be the procedure of company management in evaluating opportunities to transfer production to low-cost countries. That is the process by which it would not be neglected logistical context. Country-based logistics performance evaluation is also necessary; it will also help in understanding the relative position of the country and providing guidance on which areas require special attention, such as infrastructure, services, procedures and regulations, in order to improve the logistics performance level (Lean et al. 2014). As traditional competition becomes global, businesses often fail to take the required measures on their own in order to become more competitive, so improvement at the national level is crucial, especially for businesses directly involved in logistics (Ekici et al. 2016).

Framework as recommendations in answer to the question may be mentioned:

- Start from the broadest possible perspective.

- Select the right product.

- Select the appropriate resources.

- Propose Supply Chain.

- Make a model to be evaluated.

- Take a final decision.

In practice most of managers use to consider the given opportunity only in terms of revenues, respectively reducing individual costs and from a technical point of view that means relocation business. Yet overlooked significant problem is the emergence of a much wider supply chain. Its characteristics for inclusion cheap resources can cause unpredictable and dramatic effects in business performance. The attractiveness of cheap resources is therefore necessary to confront the achievable level of customer service, with delivery times and stocks in the Supply Chain (Gourdin 2006). Global competition opens the struggle for reducing costs and improving customer satisfaction. All companies are seeking centralization of activities to exploit economies of scale. Application of the latest technological solutions 
enables businesses to provide quality service at low cost. Slim logistics and the lowest stocks allow providers to maintain competitiveness. Such as increasing the quality of customer service and cost reasons forcing companies to work together to look for opportunities for coordinated cooperation, linking their information systems integration of legally independent entities to Supply Chain that delivers immediate and lasting health consequences.

\section{Lean Logistics}

The role of Supply chain management (SCM) has been removed unnecessarily high inventories and associated costs and optimizes time and accurate deliveries. SCM manages the flow of goods based on demand and not move supplies from top producers to retail. Lean logistics is the ability to design and manage a system for motion control a geographical location of the materials, the materials in the production of goods, and in achieving the lowest total costs (Bowersox et al. 2002). The management theory is based on the principles of elimination of useless features and improving the speed of operations and goods flow. Rapid growth of world trade and the development of electronic commerce greatly influenced by the complexity of logistics operations. Each actor in the supply chain, manufacturer, wholesaler, retailer, distributor, 3PL operator is under pressure reduction and balancing of times, costs and stock levels. They want as much as possible to streamline its logistics. This trend is particularly true for global supply chains (Grant et al. 2006). Global Lean logistics must face the challenge of transporting goods over long distances, and thus through a large number of entities. Some reports say that the entities may be involved in delivery vans. Height number of operations and factors affect the accuracy of deliveries. The ultimate goal of lean logistics is to reduce costs while improving service quality. To achieve this goal, the path may lead through the application of Six Sigma management approach. Six Sigma approach helps to understand and eliminate the adverse effects of variation (variability) in business processes. This approach in logistics may be used in the management of inventories, which favourably affects the amount of insurance reserves on the one hand, and the likelihood of lack of supplies on the other. Lean Six Sigma Logistics is a way to understanding the synergistic application of previous approaches and to removing unnecessary inventory through qualified attempts to understand and reduce variability, leading to an acceleration of the flow of goods. Companies that decided to focus on the continuous improvement of performance, currently enjoying a competitive advantage through quality, timely and accurate service. On a global scale, but also at the national level, these companies exploit the potential of becoming more massive implementation of information technology for tracking logistics activities in real time. Information systems enable real models, plan individual operations as well as to develop the necessary actions to correct the errors in the chain. The advantage of these costly and complex information solutions is that they are able to identify weaknesses, potential weaknesses supply chain has, and therefore contribute to a significant reduction in the likelihood of occurrence of system errors and untimely repairs are excessive, the joint implementation of information systems between the chain is worth.

\section{Logistics Methods}

Methodical apparatus used in logistics when planning, designing or improving Supply Chains and to manage them is a dedicated download methods from various scientific and technical disciplines, which are applied in the spirit of a systematic approach in order to lead to achieve synergies in logistics.

Logistics methods can be divided into five groups:

- Analytical methods are methods that are used primarily to analyse logistics processes and the analysis of supply, and sales of materials and goods. This group includes: system analysis, ABC analysis, value analysis, cost analysis and so on;

- Mathematical methods, including methods of operational analysis, using the case of explaining the context of the overall running of the company;

- Methods of modelling (modelling logistics systems) are useful in the accurate portrayal of the procedures and processes, for example graph theory, the network analysis methods and so on;

- Simulation methods are used for fine-tuning systems and procedures;

-Forecasting methods used for screening procedures and movements in logistics planning in future periods to predict the overall process and movement.

According to Pernica (2004) may be to the logistic methods included various mathematical - logical methods, simulation modelling, but also methods borrowed from other disciplines:

- Method of monitoring the flow of material;

- Methods for analysing and planning the use of technical means and staff;

- Methods of spatial deployment of technical equipment, facilities, warehouses and so on;

- Methods of Operational Research;

- Method of value analysis and value engineering;

- Cost calculation method;

- Statistical methods of information processing;

- Methods of multicriteria evaluation of alternatives and more. 
Other methods of Logistics division according to Viestová (2007):

- Methods of analysis processes such as mathematical statistics, stochastics, theory of errors;

- Process modelling techniques, e.g. Graph theory, queuing and so on;

- Methods of process optimization and operational analysis, game theory;

- Process control methods such as organization theory, control theory;

- Methods of evaluating processes, for example. Cost budgeting and so on.

\section{Chosen Research Results and Discussion}

We focused our research on situation in Slovak Logistics and its problem areas and also on logistics manager work and its specification.

\section{Situation in Slovak Logistics}

Slovak Logistics is mainly based on orders from the automotive, electrical and engineering industries. Ensure that both the flow of materials between producers, suppliers and customers as well as the movement of finished goods. The disadvantage of Slovak Logistics is a high concentration on road transport. Demand for transport capacity is well above the offer, which is naturally reflected in the prices. However, at higher prices it is expected to continue higher quality and accuracy. The logistics industry is constantly growing and it is only a matter of time before you notice any looming barriers such as lack of language and technically savvy workforce, infrastructure limits. Efforts to multimodality logistics solutions are a way to keep up with the West.

It is necessary to look for opportunities by creating competitive advantage in the region to stop the development of logistics at the current level of quality. State support in the areas of infrastructure development, the formation of education relevant to logistics carriers or motivation for multimodal solutions to various stimuli are just an example of how the State can contribute to the development of the logistics industry.

An analysis of the situation in Slovakia in the regional environment implies some problem areas, including in particular:

- The narrow specialization of industrial production, particularly in the automotive industry and electrical industry;

- The slow pace in the introduction of innovative solutions;

- Lack of a highly-skilled workforce;

- Slow introduction of new technologies;

- Slow development of infrastructure and poor technical and technological level of road and rail infrastructure;

- Compliance with a condition of rail interoperability;

- Uncompleted motorway corridor TEN-T;

- The low level of use of capacitive potential of existing intermodal transport terminals and weak linkage to logistics parks;

- The low level of deployment of intelligent transport systems.

Analysis of the situation in Slovakia highlights some objective factors in the external environment that may not directly affect the company management. We deal therefore with logistics manager at the production company for identification of problems in the management of competencies. Our research was carried out among 96 logistics managers of manufacturing companies in Slovakia by a questionnaire survey. We provide some selected results of research.

\section{Manager of Logistics}

Changing world and increasing globalization affects all spheres of social, technological, political and economic life. Business management belongs to the areas for which necessity flexibly and with sufficient speed to respond to changes in the surrounding environment. The technological progress will lead to a change of tasks of employees and a shift of the required competences and job specifications (Gorecky et al. 2014). The logistical process of the material flow has become extremely difficult. The consequences find themselves within an increasing complexity and diminished transparency of logistics systems in the product supply. Nevertheless, logistics cache significant rationalization capabilities within or across companies (Bauer et al. 2014). The human factor: man - the decision-making authority, also plays important role in the supplier choice process. The authority should have the ability to objectively assess all the options of the supplier choice and choose the option with the greatest benefit for the company (Černá, Buková 2016). Managers themselves are the workers, whose competence, quality and performance depends essentially on the performance and success of individual companies and the economy as a whole. Managers of organizations significantly affect the competitiveness of the company and its economic performance. Nevertheless, the development of management is not once only response to acute problem, and it is not underpinned by long-term strategy, whose implementation managers have ensured. Companies are under risk, not to have good managers, leaders, able to focus on strategically important things to learn from his own work, and effectively engage the intellectual and emotional capital that represent their collaborators (Kubeš et al. 2004; Ulrich 2009). The surveys ascertaining the competence of managers 
who are repeatedly in Germany and Sweden are placed in top positions in the ranking of "Manager of the Year 'that the success of a manager depends on their level of personal responsibility, success in conditions of uncertainty or crisis, strategic and organizational ability, for the success of demonstration measurable results and success (Dytrt 2004). In order to systematize the competencieswe can say that the self-organized dispositions always move within a region of actions that reflect the relationship of a subject to another subject or object; from the consideration of these relationships result the following four competency classes: Personal competencies, activity- and implementation-oriented competencies, technical and methodological competencies, socio-communicative competencies (Abele et al. 2015). In the field of logistics Shou and Wang (2015) cover a wide range of competences using the categories of generic skills, functional skills, SCM qualifications and leadership, SCM expertise, and industry-specific and senior management skills. In contrast to the existing literature, which depicts competences as discrete and factor-based, Derwik et al. (2016) say that practice show that managers use competences in combination, which in turn creates synergies. Human resource managers gain in-depth understanding of the competences, and thereby can assist staff in recruitment and development work toward improved business performance and financial competitiveness. The present corporate job is very challenging. Every business has to face competitions from multiple dimensions and directions; the business in 21 st century can survive and succeed only if it is able to fulfill the challenges of the present demands regarding logistics (Neerajaa et al. 2014). Competent manager can be understood as complex abilities and other assumptions serving performance management. Skills have both individual and social dimension, unlike qualifications express concrete action in real-world situations. The competencies in fact include both self-development and adaptation that can be observed in practical tests for competency management in a dual focus, both in the focus on identifying and eliminating deficits and, secondly, to focus on the development of individual potential. Managers stressed the relevance of having specific organisational culture values and behaviours, such as the use of face-to-face and open communication, cooperation between employees and long-term approach to management (Bortolotti et al. 2015). Traditionally supply chain managers, whatever their specific role are concerned with the 'middle phases' of product and service life cycles, where operational roles such as the generation of formal contracts, negotiation, contract compliance, expediting, planning and scheduling have been their focus. The changes in the last decade bring the fact that not only have these activities changed significantly, frequently through various forms of standardization and automation, but also supply chain professionals have become more actively involved in strategic decision-making (Wilson, Barbat 2015).

Our research pointed to the fact that the competency models and standards process are used mainly in large companies, which are trying to develop competencies of their managers with respect to business needs. We can say, that Logistic Manager Job is coordinating all those involved in the logistics chain, i.e. planning and management of logistics activities associated with the management of material flows. Setting targets, standards and guidelines necessary to ensure the quality and quantity. Complete management of the central warehouse, inventory monitoring, securing and checking inventory, determination and management of the entire logistics strategy of the company. Logistics manager participates in transit and transport, in dealing with transport documents required for customs and mail delivery, evaluation carriers. Managers shipment planning and contributes to improving the work efficiency in the operation, cooperation in the development of business and operating strategies, plans and budgets. His work requires highly professional and responsible supervision of all activities related to logistics companies as the management of all flows from goods receipt to storage and final distribution to the client. Its scope management, distribution of tasks and monitoring their implementation, coordination and management of a team of people at middle and lower management to the lowest level of workers, that manages employees. They need the ability to motivate and correct guidance to individual departments. Further coordinate activities between departments (purchasing, customer service and planning). Logistics Manager Job is very stressful and requires quick thinking and flexible decisions when problems arise. His work includes roles operative solution to the problems the implementation of corrective measures and fully addresses the problems leading to maximum customer satisfaction. They will require good communication skills when dealing with potential claims and incurred with the customer. They need skills in interpretation and reporting of indicators such as inventory accuracy, inventory value in the manufacturing and warehouse terminal and turnaround stocks. Logistics manager must have knowledge of the rules of the Labour and Employment of, internal regulations and organizational guidelines of the company. It should also have knowledge of delivery conditions internationally. In addition to all the above knowledge and skills it needed his willingness to be on call 24 hours a day, in case of problem such as transport, export, import, and it is necessary to solve the problem immediately.

\section{Deficiencies in Competences}

In corporate governance, we found the biggest gaps, especially in strategic management - only $23 \%$ of surveyed firms deal with strategic logistical planning. In the case of setting strategic goals, these are not sufficiently addressed and there is also a discrepancy between the strategic and operational management. Managers do not understand the strategic importance of logistics in the company and the fact that logistics in the course of its development, changing from a tactical executor of marketing available, how to deliver the goods on the market, with the active co-business strategy and receives the form of horizontal and vertical integrated system. Managers see a major problem in the area of risk management and the use of modern management methods and tools. 
The research brings also interesting results in the field of required type and also developed competences. Although companies prefer from their managers technical competence, development is most focused on managerial competence. Our research pointed out certain deficiencies in professional competencies of logistics managers, which are essential for the present and especially for the future management; these are the following two areas:

1. Competencies in the field of production planning and intralogistics:

- "Vicious circle" for emergency planning;

- Work with the complete structure of production planning and control;

- Understand exactly the mechanism (MRP conditions, advantages and disadvantages);

- Properly used by an MPS (Master Production Schedule);

- Evaluate the effectiveness of scheduling deadlines and capacitive balance;

- Use heuristics for scheduling (creating sequences) production batches;

- Correctly calculate an interim period in respect of production inventories uncompleted production;

- Apply the TOC (theory of bottlenecks) for production planning and control;

- Assess the appropriateness of the deployment of advanced scheduling (APS);

- Use of computer simulations for production planning and control;

- Set up systems visualized by the drag of the management of material flows;

- Use tools "a lean production";

- Apply CCPM (Critical Chain Project Management) to plan projects.

2. Competencies in the field of purchasing and inventory management:

- Correctly identify and apply the criteria for the categorization (classification) in stocks;

- Analyse existing inventory management systems for their effectiveness;

- Determine the economically optimal procurement and production batches for resupply;

- Calculate and maintain insurance stocks within the models SIC (Statistical Inventory Control);

- Kanban (the conditions for the deployment and calculation of parameters);

- Effectively select appropriate system for resupply according to their purpose and character;

- Evaluate the economics of a particular system of replenishing stocks;

- Understand the principle and the ability to Shopping Marketing;

- Efficiently organize operative purchase;

- Properly define the interface between the operational and strategic purchases;

- Compiled a matrix of strategic positions the company on a shopping market;

- Operate within the concepts of SCM (Supply Chain Management).

We can find the reason of this situation in traditional approach to company management and lack of qualified workforce in this sector, lack of interest in studying technical direction as well as the absence of the Faculty of Logistics in Slovakia. The reason may be sometimes also an effort to obtain cheaper employees at the expense of competence.

\section{Proposal for Measures}

We propose some measures for problem solution:

- Corporate training.

Corporate Training (formerly corporate education) form (in addition to education and vocational retraining Studies focused on the job), part of continuing professional education, which called for: All forms of professional and vocational training during working life, after vocational education and vocational training ... "with this type of education" has a direct link to professional classification and application of an adult, and thus its economic activity. Belcourt and Wright (1998) note that human capital is the value whose price increases along by how it is used and that some of the most successful organization in the world built its strategy on the idea that human capital, i.e. smart and efficient workforce can become a major competitive advantage of the company. Education and formation of the working skills of managers in the modern from becoming a lifelong process, and the main role here should play and their organization organized training activities. Only competent management company can properly manage, exploit advances in science and technological development in the specific conditions of globalization.

- Changes in society and the need for lifelong learning.

Developments in technology and the advent of the information society, globalization of the economy and the transformation of labour markets underscore the strategic importance of education, training and learning. Prospects for the development of each country is a learning society in which already not enough to get initiation education to citizen life work and participate in society. There is a need for lifelong learning the fulfilment of the aims above all to create conditions for providing opportunities and participation in education for all citizens. At the same time also they perform important social objectives, such as increasing the ability of citizens to assert themselves on the labour market in the changing socio-economic conditions, personal development of individuals in accordance with its needs and capacities, 
increasing citizens' participation in governance, supporting social cohesion activities aimed at Sustainable Development. The term lifelong learning include everything learning throughout life with the aim of improving knowledge, skills and competences within a personal, civic, social and employment prospects. Already Memorandum on Lifelong Learning 2000 mentions that Europe gets into the era of knowledge, in which leads to rapid changes in learning, life and work. In knowledge society is becoming paramount date information, knowledge and skills. Increasingly, there are new insights, and new technology, so that in humans almost all professions, if not try to constantly renew occurs increasingly rapid obsolescence of acquired knowledge and skills. This concept is elaborated in the Long Life Strategy of Slovak Republic. Slovakia is relatively abundant supply of education in logistics in the form of courses, but it is necessary to change the philosophy of education at company level. Random access to education needs to be changed to the system approach and the ideal would be to move the company into the plane of knowledge-based organizations.

\section{Conclusions}

Logistics plays a key role in economy in two significant ways. For the first, logistics is one of the major expenditures for businesses, thereby affecting and being affected others economic activities. For the second, logistics supports movement and flow of many economic transactions it is an important activity in product as well as services sale. To understand the role of logistics in corporation management from the systematics point of view, we must realize the fact that logistics determines disposal of product for customers. If the product will not be offered delivered at the right place and the right time being in a good safety, the product sale is not possible. By affecting logistical functions, all economic activities are being influenced within the supply chain (Lambert et al. 2000).

Globalization, as we had seen, can be analysed from several approaches. According to their effects they differ based on which environment they are present. To benefit from it, there is cooperation needed all the time on micro-, macro and even global level. The basis of this cooperation is the enhancing logistical activity, the enlarging supply chain, which all have a major effect on the growth of competitiveness. From the perspective of supply chain management, one the priority task is minimizing risk, which is often connected with mistakes; by the supply chain risk we understand the probability of adopting the inadequate strategy, wrong decisions, non-optimal configuration of a logistics system, etc. Essential task of management is to be aware of changes occurring both within the company and in the external environment so that logistics effort can be modified as required to continually add value to the final customer.

Globalisation, the rapid growth of new competitors, the dynamic pace of technological change, the increasing speed of access to information, the growth of innovation and the complexity of the manufacturing process are some of the determinants that strongly influence the success of the company the fierce market. It is not enough just to dispose modern technologies that streamline the production process, it is necessary to draw attention to human resources. It is the people who put into motion and handle other sources of business. They constitute the company's most valuable and important resource. Their managers in organizations substantially affect the competitiveness of the company and its financial results. Nevertheless, management development is often the only answer to the acute problem and not supported by long-term strategy, the implementation of which should ensure managers. Companies are thus exposed to the risk not have leaders of managers capable to focus on strategically important things to learn from their own work and effectively engage the intellectual and emotional capital represented by their co-workers. It is necessary that managers occupying an important position in the company possess certain skills, abilities, i.e. competences. Work of Logistics Manager requires specific competences deriving from the description of their activity and performance of the whole working process. Those management competencies were really reliable strategic basis for the development of people needs to be properly identified and educated. Shortcomings in this field of management have a negative impact on the functioning of the company and its competitiveness.

\section{Disclosure Statement}

This article was prepared within the project VEGA 1/0696/16 Design of methodology for measuring quality of life in a regional context and VEGA 1/0244/16 Personnel marketing as a new approach of the ensuring and maintaining the skilled workforce in Slovak companies.

\section{References}

Abele, E.; Metternich, J.; Tisch, M.; Chryssolouris, G.; Sihn, W.; ElMaraghy, H.; Hummel, V.; Ranz, F. 2015. Learning Factories for Research, Education, and Training, Procedia CIRP 32: 1-6. https://doi.org/10.1016/j.procir.2015.02.187

Bauer, W.; Ganschar, O.; Gerlach, S. 2014. Development of a method for visualization and evaluation of production logistics in a multi-variant production, Procedia CIRP 17: 481-486. https://doi.org/10.1016/j.procir.2014.02.027

Bauman, Z. 2000. Globalizácia. Dôsledky pre l'udstvo. Bratislava: Kalligram.

Belcourt, M.; Wright, P. C. 1998. Vzděláváni pracovniků a ř́zeni pracovního výkonu. Praha: Grada Publishing.

Bortolotti, T.; Boscari, S.; Danese, P. 2015. Successful lean implementation: organizational culture and soft lean practices, International Journal of Production Economics 160: 182-201. https://doi.org/10.1016/j.ijpe.2014.10.013

Bowersox, D.; Closs, D.; David, J.; Cooper, M. B. 2002. Supply chain logistics management. New York: McGraw-Hill/Irwin. 
Ceniga, P.; Šukalová, V. 2012. Logistika v manažmente podniku. Žilina: EDIS.

Černá, L.; Buková, B. 2016. Supplier evaluation methodology in the logistics company, Procedia Engineering 134: $377-385$. https://doi.org/10.1016/j.proeng.2016.01.023

Derwik, P.; Hellström, D.; Karlsson, S. 2016. Manager competences in logistics and supply chain practice, Journal of Business Research 69(11): 4820-4825. https://doi.org/10.1016/j.jbusres.2016.04.037

Drahotský, I.; Řezníček, B. 2003. Logistika - procesy a jejich řizení. Brno: Computer press.

Dytrt, Z. 2004. Manažerské kompetence v Evropské unii. Praha: C. H. Beck.

Ekici, Ö. S.; Kabak, Ö.; Ülengin, F. 2016. Linking to compete: logistics and global competitiveness interaction, Transport Policy 48: 117-128. https://doi.org/10.1016/j.tranpol.2016.01.015

Gorecky, D.; Schmitt, M.; Loskyll, M. 2014. Mensch - Maschine - Interaktion im Industrie 4.0 Zeitalter, in T. Bauernhansl, M. ten Hampel, B. Vogel-Heuser (Eds.). Industrie 4.0 in Produktion, Automatisierung und Logistik: Anwendung, Technologien. Migration. Wiesbaden: Springer Vieweg, 525-527. https://doi.org/10.1007/978-3-658-04682-8_26

Gourdin, K. N. 2006. Global logistics management. Oxford, UK: Blackwell Publishing.

Grant, D.; Lembert, D. M.; Stock, J. R.; Ellram; L. M. 2006. Fundamentals of logistics management. New York: McGraw- Hill education.

Kubeš, M.; Spillerová, D.; Kurnický, R. 2004. Manažérské kompetence: Zpưsobilosti výjimečných manažerů. Praha: Grada Publishing.

Lambert, D.; Stock, J. R.; Ellram, L. 2000. Logistika. Praha: CP Press.

Lean, H.; Huang, W.; Hong, J. 2014. Logistics and economic development: experience from China, Transport Policy 32: 96-104 [online], [cited 10 March 2017]. Available from Internet: http://www.sciencedirect.com/science/article/pii/S0967070X14000122

Lindsey, Ch.; Mahmassani, H. S.; Mullarkey, M.; Nash, T.; Rothberg, S. 2014. Regional logistics hubs, freight activity and industrial space demand: econometric analysis, Research in Transportation Business \& Management 11: 98-104. https://doi.org/10.1016/j.rtbm.2014.06.002

Manganelli, R. L.; Klein, M. M. 1998. Reengineering. Warszawa: Polskie Wydawnictwo Ekomoniczne.

Melović, B.; Mitrović, S.; Djokaj, A.; Vatin, N. 2015. Logistics in the function of customer service - relevance for the engineering management, Procedia Engineering 117: 802-807. https://doi.org/10.1016/j.proeng.2015.08.255

Neerajaa, B.; Mehtab, M.; Chandanic, A. 2014. Supply chain and logistics for the present day business, Procedia Economics and Finance 11: 665-675. https://doi.org/10.1016/S2212-5671(14)00232-9

Pernica, P. 2004. Logistika (Supply Chain Management) pro 21. stoleti, 1.-3. díl. Praha: Radix.

Pichanič, M. 2004. Mezinárodní manažment a globalizace. Praha: Nakladatelství C. H. Beck.

Shou, Y.; Wang, W. 2015. Multidimensional competences of supply chain managers: an empirical study. Enterprise information systems [online], [cited 10 March 2017]. Available from Internet: http://www.tandfonline.com/doi/abs/10.1080/17517575.2015.1080303

Ulrich, D. 2009. Mistrovské rízení lidských zdrojů. 1. vyd. Praha: Grada Publishing.

Verhetsel, A.; Kessels, R.; Goos, P.; Zijlstra, T.; Blomme, N.; Cant, J. 2015.Location of logistics companies: a stated preference study to disentangle the impact of accessibility, Journal of Transport Geography 42: 110-121. https://doi.org/10.1016/j.jtrangeo.2014.12.002

Verstrepen, S.; Cools, M.; Cruijssen, F.; Dullaert, W. 2005. Creating and managing horizontal partnerships in logistics: empirical evidence and guidelines for implementation, Proceedings of the BIVEC-CIBET Transport Research day, 163-178 [online], [cited 02 March 2017]. Available from Internet: http://hdl.handle.net/10067/561550151162165141

Viestová, K. 2007. Lexikón logistiky. Bratislava: Iura edition.

Wilson, K.; Barbat, V. 2015. The supply chain manager as political-entrepreneur?, Industrial Marketing Management 49: 67-79 [online], [cited 11 March 2017]. Available from Internet: http://www.sciencedirect.com/science/journal/00198501/49

Yu, K.; Cadeaux, J.; Song, H. 2016. Flexibility and quality in logistics and relationships, Industrial Marketing Management. 